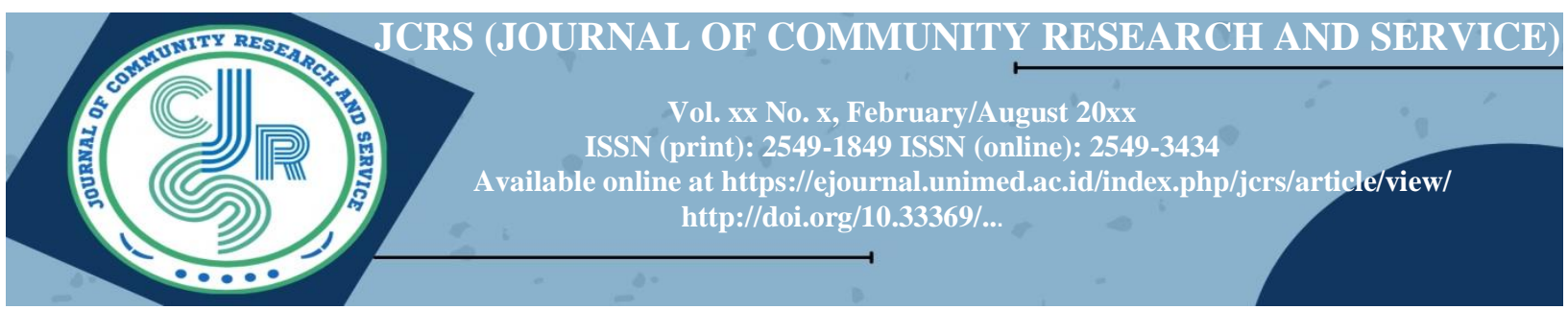

\title{
Socialization of Application Digital Media for Hybrid Learning
}

\author{
${ }^{1}$ Fatin Nadifa Tarigan, ${ }^{2}$ Alwi Fahruzy Nasution, ${ }^{3}$ Taufika Hidayati, \\ ${ }^{4}$ Joko Priono, ${ }^{5}$ Epi Supriyani Siregar \\ ${ }^{1}$ English Education Study Program, Universitas Pembinaan Masyarakat Indonesia,Indonesia \\ Inadifafatin11@gmail.com \\ 2,4,5 Physical Education, Health and Recreation Study Program, Universitas Pembinaan \\ Masyarakat Indonesia,Indonesia \\ 2,4,5 alwifahruzynasution@gmail.com, jokopriono257@gmail.com,episupsiregar1216@gmail.com \\ ${ }^{3}$ Law Study Program, Universitas Pembinaan Masyarakat Indonesia,Indonesia \\ ${ }^{3}$ taufikahidayati30@gmail.com
}

\begin{abstract}
The unstable condition of Covid-19 pandemic caused teachers be innovative in combining both online learning and face to face learning. Nevertheless, the application of digital media during hybrid learning is still a big issue for teachers in SD Adhyaksa, Medan City, North Sumatra Province. In consequence, it is necessary to hold community service by means of socialization of application digital media for hybrid learning. This service aims to socialize and offer training related to the use of online study through Google Classroom and Google Form to teachers and employees at Elementary School. The methods used to carry out this service activity were lecturing method and direct practice. It started from providing material introduction and direct practice of using Google Classroom and Google Form for teachers. With a variety of features it has, Google Classroom can be used to demonstrate or visualize concept of lessons with no face to face needed. From this service activity the teachers who tried Google Classroom and Google Form got good results. They understood how to apply digital media either in online learning or in offline learning. After getting materials and practices for applying digital media, Google Classroom and Google Form, teachers are accustomed to use these online media for hybrid learning.
\end{abstract}

Keywords: socialization, digital media, Google Classroom, Google Form, hybrid learning, covid-19

Article history: Received:xxx; Revised: xxxx; Accepted:xxx; Available online: xxx (7.5 pt)

How to cite this article: Family name, A.K., Family Name, A.P., and Family name, D. (xxxx) Title of Manuscript. Int. Journal of Community Research and Secvice, $\mathrm{x}(\mathrm{x}), \mathrm{xxx}-\mathrm{xxx}$. (7.5 pt)

https://doi.org/10.14710/ijred.x.X.Xxx-xxx

\section{Introduction}

The impact of the pandemic of COVID-19 has a certain influence on various world. Because of the pandemic of this novel coronavirus in terms of COVID-19, the education life has been changed a lot. To keep the social distance between human being to prevent from being infected, many schools applied distance learning to minimize the spread out of this coronavirus infection. As results, educators should be innovated to keep on the learning process but away from being infected for education during pandemic. The education world has begun to abandon learning offline, leading to online learning. In this case improving the quality of education is an absolute [1].

E-learning becomes one of the exciting and hot innovations discussed as a digital media for education, because e-learning is a learning system using new methods by utilizing internet technology that can be accessed anytime and anywhere so learning is not only done in the classroom and only during class hours, but can also be done outside of class hours when needed [2]. Online learning creates 'anywhere 
and anytime' interaction among learners, offers them access to instructional resources, and provider opportunities to learn and practice the target language beyond the classroom [3]. It has the best advantages and has a vast wealth of learning resources. Five functions of using the internet as a learning resource, namely: media as technology, media as tutor or teacher, media as socializing agents, media as a motivator for learning, and e). media as problem solving [4].

However, despite all advantages of online learning, the educators does not necessarily leave the traditional face-to-face learning. In fact, by combining both traditional and online learning which is popularly known as hybrid learning. Hybrid learning is defined as learning that combines face-to-face learning activities with computer and internet technology-based learning [5]. It facilitates the students and the teachers in learning activities via the internet. Husamah also emphasizes that hybrid learning as learning that combines various methods of delivery, teaching models, and various technological media [6]. In addition, Widana [7] states that hybrid learning not only reduces the distance that has existed between students and teachers but also increases interaction between the two parties. In can be concluded that hybrid learning combines online learning with face-to-face learning. Hybrid learning is beneficial for learners because internet-based classes have no time or place constraints, so learners with varied learning styles can work at their own speed and in any convenient location. However it needs to be an adjustment, which depends on the condition of the school and the student's place of residence [8].

One of media that is applicable for hybrid learning is Google Classroom. Google classroom is an internet-based service provided by Google with an e-learning system. Google Classroom has some benefits such as: classes can be prepared instantly or easily by teachers; students can do assignments and submit answers to assignments; paper efficiency with the educational process with the online media model [9]. In addition, teachers can create classes, distribute assignments, talk and do management. Designed to assist the learning activities, the teachers can send announcements and actively initiate class dialogue while students can collect module assignments between each other and connected in every classroom, through the mobile application or smartphone. Class can used for free and free of charge and there is no access to ads. All information in the user's convenience as well as stored.

Not only application in the form of online educational media such as Google Classroom, teachers also can use Google Forms. Google forms is part of the service component contained in Google Docs. Google forms is also used for carry out activities in the form of exercises, assignments, or online surveys [10]. The benefits of Google Forms include: Distribute assignments/practices on Google Forms; Collecting survey results in the form of comments on Google Forms; Collecting information such as video, audio, pdf, document, photo in Google Form; Create an online registration form for schools on Google Form; Share field data via Google Form .

With the socialization on the application of Google Classroom and Google Forms for hybrid learning, it is expected that teachers will be able to improve their professionalism in teaching, motivate the students, and solve student problems. Then, it is expected that teachers can be more innovative in developing learning activities so that they are able to pass the students with good criteria and be able to equip students with skills that can be used in social life, especially in meeting economic needs.

\section{Method}

The method used in community service activities with the theme of socialization of digital media for Hybrid Learning by way of lecturing method and direct practices. It was done with the aim that teachers can understand the socialization material well and able to put it into practice. Measurement of the success rate of socialization and this training is obtained by being able to create an account on Google Classroom and Google Form was given after the implementation of the activity and also the results of the work given. Every teacher prepares their own smartphone and email after getting explanation of the material provided. Furthermore, teachers immediately practice. As for obstacles faced by teachers, the service team directly provided solutions from problems that arise. The implementation mechanism and service flow include as follows. 
1. Socialization related to the introduction and development of digital media in general. Various online media developments can also be applied to support implementation online learning process, such as Google Classroom, Edmodo, Google Meet, Zoom and instant messaging services such as Whatsapp and Telegram. Online learning connects participants students with learning resources that are physically separated or even far apart (not face to face) face at school) but can communicate with each other, interact or collaborate.

2. Socialization related to the application of digital media specifically, such as: Google Classroom and Google Forms. The stages of socialization and related training development of digital media in particular are Google Classroom and Google Forms consists of:

1) Preparation: at this stage, Google Classroom and Google materials are created. The form is in the form of a presentation slide and also a face-to-face determination directly in the room which has been prepared by the school as a place to be used in implementation of community service in the form of socialization and training;

2) Implementation: at this stage training was carried out by explaining the material. The discussion gave assignments to see the results of the training that has been delivered to measuring the increase in participants' ability to use Google applications : Google Classroom and Google Forms;

3) Evaluation: at this stage an evaluation of the results of the socialization and training activities was carried out that has been done. Evaluation was carried out after finishing providing material, discuss, provide exercises and assignments and giving assignments independently participants in a task related to the evaluation of success assessment and capacity building after socialization of creating a Google Classroom account, adding students, assign assignments in Google Classroom and view assignments and use form from Google Form when you want to make questions for students in the evaluation process learn how to teach. It was intended to assess the success of socialization and training held.

\section{Findings}

There were 3 steps in implementing the socialization in SD Adhyaksa Medan. This service activity was started by preparation of activities in which participant forms to partner teachers and socialization activities were distributed. The purpose of this activity is to provide information on the agenda of activities, the objectives of implementing the activities and seeking agreement on the schedule. The socialization was attended by 20 (twenty) teachers. The activity was opened by the Principal and the Implementing Committee. It also carried out the submission of practice questions along with discussions that were practiced during socialization.

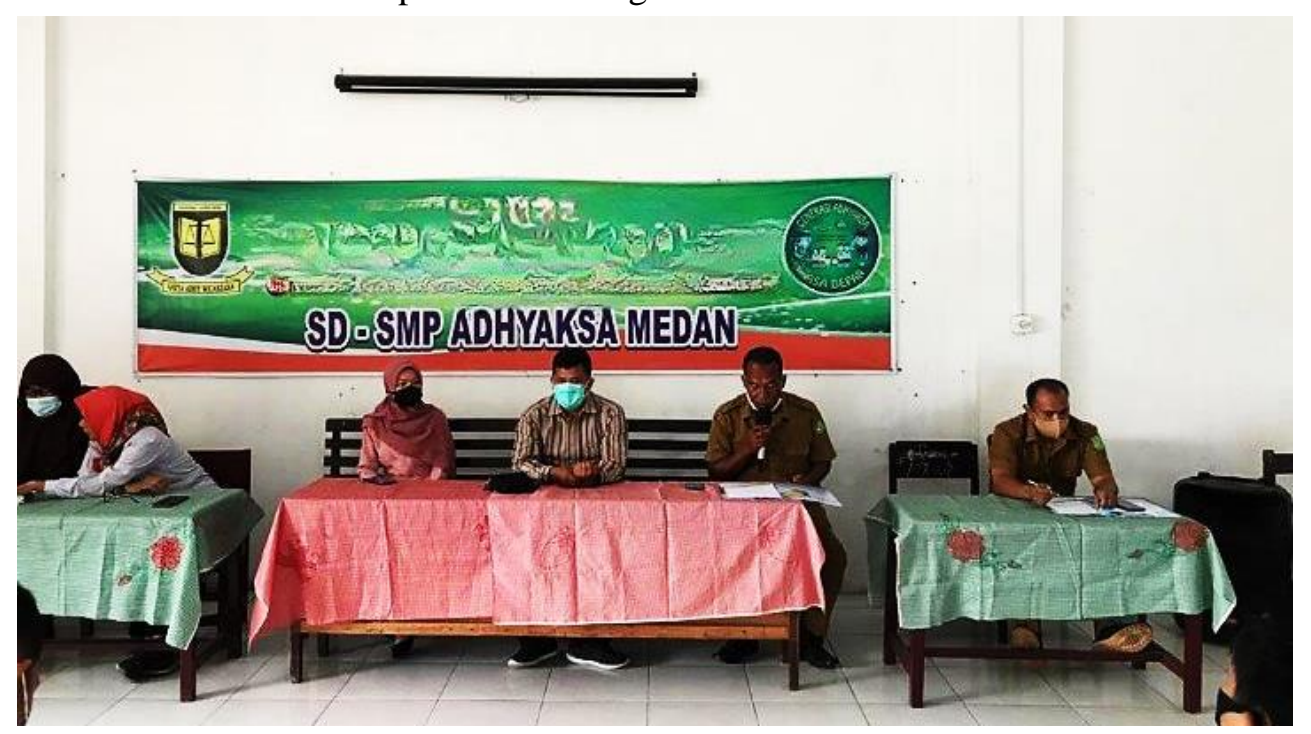

Fig. 1. Opening Socialization

JCRS (Journal of Community Research and Service),6(1), 2022 
In the implementation, digital media were introduced which participants (teachers) still did not understand well how to use them. The introduction was carried out with the assitance of presenters and modules. The activity then continued with the explaination of the material from the presenters, then participants were given training to create Google account for Google Classroom and Google Form and then they learned to make material simulations that would be uploaded on the Google Classroom during teaching and learning activities.

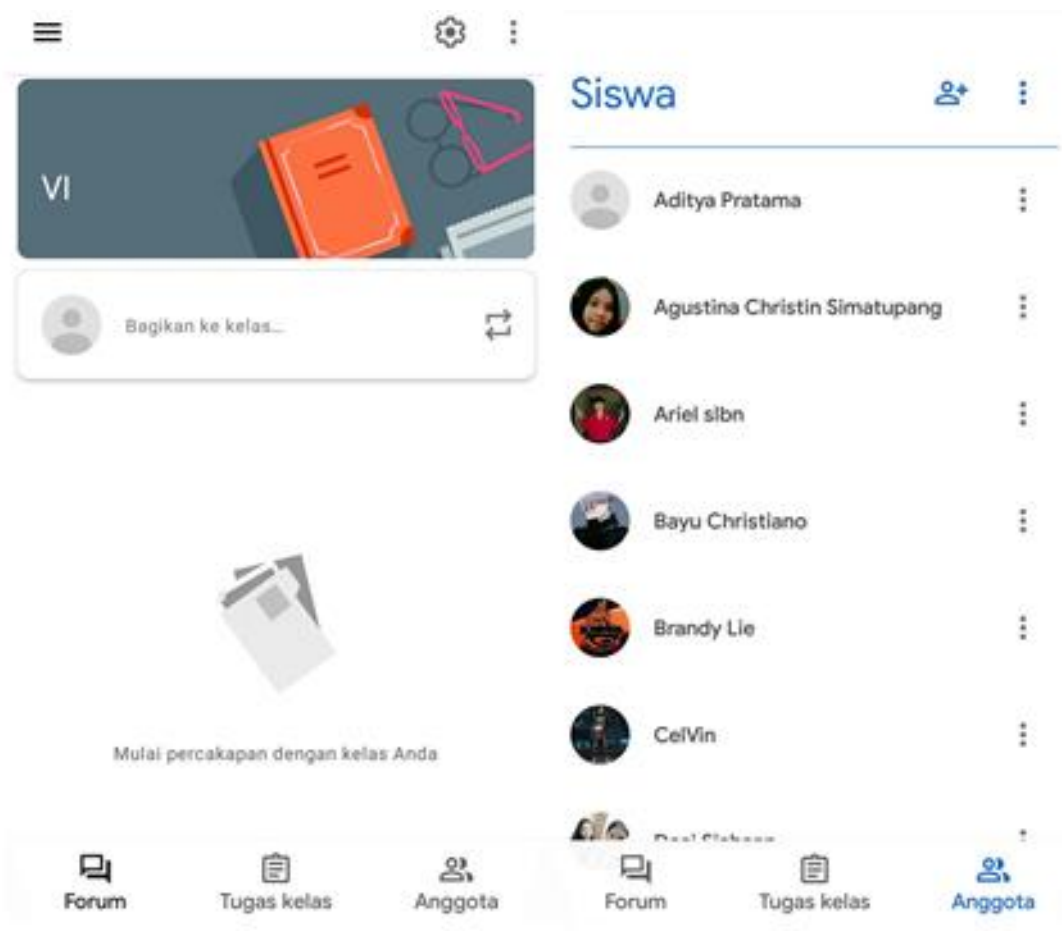

Fig. 2. Creating Google Classroom for Students

The closing activity was filled with hospitality and impressions as well as suggestions from participants during this community service activity to improve the next activity. The Organizing Committee and Presenters motivate the participants to continue learning and improve their competence, both individually and groups. It was expected that schools, especially teachers can implement and improve the knowledge that they got from this activity.

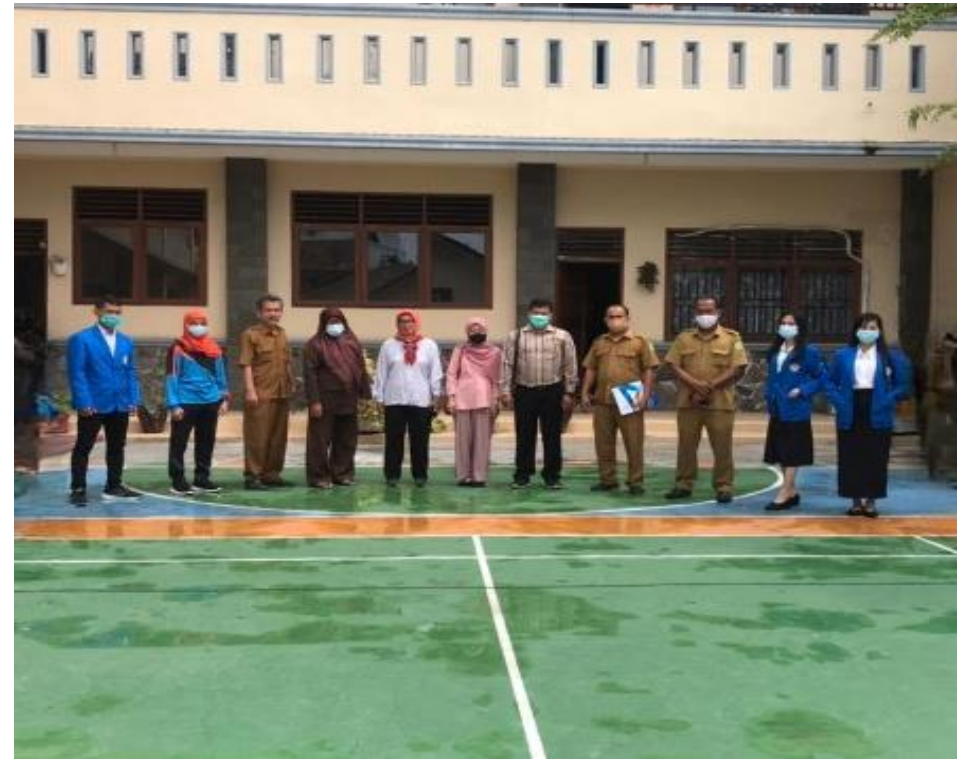

Fig. 3. Closing activity with Principal and participants 


\section{Discussion}

Based on the findings that the teachers of SD Adhyakasa were not familiar using hybrid learning applications. Only $70 \%$ were proficient and skilled in using digital media since the limitation of information and training during Covid-19 pandemic. After this socialization was done, almost all teachers and students were familiar with hybrid learning applications with assistance of digital media. The percentage can be seen as follows.

\section{Percentage of Mastering Digital Media for Hybrid Learning}

Expert in using digital media $\quad$ Not expert in using digital media

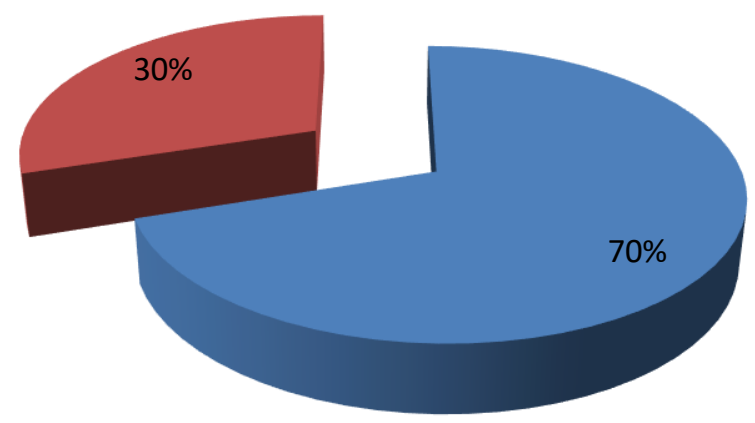

Fig. 4. Percentage of Mastering Digital Media for Hybrid Learning

Starting with the practice of Google Classroom application. After the participants knew well the use of Google Classroom, then material was given regarding the use of Google Form. During the delivery of the material, participants were welcomed to ask some things that were not clear to be understand so that the presenter can directly answer them. the Google Classroom application was useful for teachers if they want to give assignments to students. Teachers needed to send assignments to the class he has made in this application and the students provide answers according to the deadline allotted time.

From the socialization and training that has been given, it was obtained that the teacher felt very helpful because in this pandemic, teachers were required to carry out the online learning process. With this socialization for teachers, they were able to apply google form and google classroom.. In this application also the teacher can interact with their students such as asking questions or answer questions posed by students. Therefore both applications are able to make the learning process be effective and efficient.

\section{Conclusion}

Based on the discussion, conclusions were obtained:

1) the application of digital media in hybrid learning model at SD Adhyaksa was carried out through the stages of preparation, implementation and evaluation. The preparation stage includes the coordination meeting stage and preparation. The implementation stage was carried out face-to-face meeting where the teachers were asked to create Google Classroom and Google Form by theirselves. While the evaluation stage was carried out to measure the application of digital media in the hybrid learning for increasing teachers' knowledge in media and improving student learning outcomes.

2) Of the total participants, 90 percent have been able to apply Google Classroom and Google Forms on their respective cellphones or laptops. They have been able using these two applications as learning media during this pandemic. It is expected that by this socialization, the teachers will be more enthusiastic increase their knowledge to teach their students. Teachers who have attended training also expected to be able to teach other teachers who were JCRS (Journal of Community Research and Service),6(1), 2022 
unable to attend this training so that all teachers can use these two applications for the learning process since digital media increase students' motivation and learning outcomes in limited face-to-face learning and in hybrid learning model.

\section{References}

[1] Iffah, N. P ., Chasanah, K. A. and Ilmi, K. N. The role of broadband learning center (BLC) in elevating career woman technological capabilities (study in Wonorejo, Surabaya)," ACM Int. Conf. Proceeding Series. 2018. doi: 10.1145/3206129.3239437.

[2] Saragih, J.M.,et.al. Application of Blended Learning Supporting Digital Education 4.0. Journal of Physics: Conference Series.2020. 1566 (2020) 012044.

[3] Fithriani, R., \& Alharbi, M. A. The adoption of Edmodo in a hybrid EFL writing class: What do Indonesian students and lecturers say? Asian EFL Journal. 2021; 28(2.3), 38-60.

[4] Plomp, T., \& Ely, D. P. International Encyclopedia of Educational Technology, 2nd edition. New York: Elsevier Science, Inc; 1996.

[5] Galus, S.A., Arifin, \& Sulkifly. Kesiapan sekolah dalam pengelolaan model pembelajaran hybrid learning di SMA kota Gorontalo. Student Journal of Educational Management, 2021; 1(1), 41-56.

[6] Husamah. Pembelajaran bauran (blended learning). Padang: Prestasi Pustakarya; 2014.

[7] Widana, I. W. The effect of digital literacy on the ability of teachers to develop HOTS-based assessment. Journal of Physics: Conference Series $1503 \quad$ (2020) 012045.2020. https://doi.org/10.1088/1742- 6596/1503/1/012045..

[8] Setyo, D. Model-model pembelajaran hybrid (seri 3 hybrid learning). 2021. Available at http://dedysetyo.net/2021/01/02/model-model-pembelajaran-hybrid-seri-3-hybrid-learning/.

[9] Google. (2021). google.com. Retrieved from https://id.wikipedia.org/wiki/Google_Kelas

[10] Sianipar, A. Z. Penggunaan Google Form Sebagai Alat Penilaian Kepuasan Pelayanan Mahasiswa. Journal of Information System, Applied, Management, Accounting And Research, 2019; 3(1), 1622. 